\title{
President of state in face of mortality: Exploring implications of Drnovšek's radical shift on media, public relations and relationships between the two
}

Accepted in: Public Relations Inquiry

Author:

Alenka Jelen

(Communications, Media \& Culture), University of Stirling, UK

Corresponding author: Alenka Jelen, Communications, Media \& Culture,

University of Stirling, Stirling FK9 4LA, UK.

Email: alenka.jelen@stir.ac.uk 


\section{Abstract}

The purpose of this article is to explore the influence a radical transformation of a politician facing mortality has on public relations, media and relationships between the two, focusing on the case of former Slovenian President Janez Drnovšek, who towards the end of his mandate transformed from a conventional, pragmatic politician to a New Age critical spiritual leader. Drawing on grounded theory approach, 12 qualitative interviews with journalists and Drnovšek's political advisers were conducted. The results show that while the opinions and perceptions of Drnovšek's change differed significantly between political advisers and journalists with the former neutralising it and the latter emphasising it, the methods of communication and relationships between them somewhat surprisingly remained the same, indicating their endurance and resistance to a radical political transformation in the process of public dying. What changed were Drnovšek himself and his 'private' style of communication with the media, and journalistic routines, resulting in amplified media coverage of an unconventional and 'loopy' President.

\section{Keywords}

Public relations, journalism, relationships, death and dying, president, Janez Drnovšek.

\section{Introduction}

With the increase of political figures diagnosed with terminal illness, death-related personal transformations, including unexpected, impulsive deviations from conventional actions, loss of patience and rationality, reconsideration of priorities and seeking to 'change the world for the better' (Hinton, 1972; Kearl, 1989; Elias, 2001; Kübler-Ross, 2009), have started from the private world of individuals entering the public sphere (Bryant, 2007). These changes bring important implications for how politicians generate, react and handle public communication of 
the last period of their life, yet have - despite growing death awareness movement and body of knowledge in sociology, psychology, philosophy and anthropology- received hardly any attention in public relations and media studies (Bryant, 2007; Van Brussel and Carpentier, 2014). With the purpose to explore the influence a radical transformation of a politician in the process of public dying has for public relations, media and relationships between the two, this study uses the case of Slovenian President Janez Drnovšek, who in a pronounced public reaction to his mortality in the last two years of his mandate transformed from a conventional, pragmatic and reserved politician to a New Age critical spiritual leader, surprising the media and the public with several unexpected and for head of state unusual activist-oriented initiatives, sharp critical attitudes and open communication. This transformation represented a serious challenge for political advisers communicating the President, journalists covering the President and relationships between the two.

To gain better understanding of implications Drnovšek's shift had on public communication, the article first outlines Drnovšek's political career before and after his deviation from a conventional politician. His shift is primarily explained as a reaction to his terminal illness through thanatology perspective (Hinton, 1972; Kearl, 1989; Elias, 2001; Kübler-Ross, 2009), but also contextualised in a broader religiological framework as a symptom of increasing pervasiveness of New Age culture (Črnič, 2007). Drnovšek's transformation received an extraordinary media attention, occasionally escalating into media-hypes at the time when his public relations, characterised by immaturity issues, was to a large extent based on improvisation and sweetheart relationships with the media. His public communication further increased in complexity with Drnovšek's 'private' blog, separate from official communication of the Office of the President. To explore how Drnovšek's shift influenced media, public relations and relationships between the two, 12 qualitative expert interviews with political advisers and journalists, representing the key actors involved in the social construction of 
politics (Davis, 2010), were conducted. The results introduce perceptions and opinions the advisers and journalists had of Drnovšek's change, how it influenced journalists and their practices, on the one hand, and his public relations, on the other hand, and what implications it had for relationships between the media and the Office of the President.

\section{Political career of Janez Dnovšek}

Janez Drnovšek represents one of the most successful Slovenian politicians, who throughout his political career occupied the highest political positions. He was the first elected President of the Presidency of Yugoslavia (1989-1990) and after Slovenian independence in 1991 served as Prime Minister almost uninterruptedly for a decade (1992-2002) until he was sworn in as President of the Republic of Slovenia (2002-2007). As the Prime Minister, he guided Slovenia through successful political and economic post-socialist transition in a skilled, moderate, calm, technocratic and instrumental leadership style. He built an image of a charismatic, rational, intelligent, experienced, knowledgeable, confident, trustworthy, pragmatic, dignified and internationally reputed politician, which was - somewhat unusual for contemporary mediaoriented societies - not based on strategies of media appearance, populist approach or intensive public promotion, but originated from his diplomatic abilities to act in the background (Vreg, 2001, 2004; Črnič, 2007; Repovž 2007). This image and leadership style prevailed in the first part of his presidential mandate, yet with his personal transformation and shift in public actions significantly changed in 2006.

\section{Drnovšek's personal transformation and shift in public actions}

With transference of attention from narrow areas of politics and economy to ecology, spirituality and social issues and with transition from background activities to intense, heterogeneous communication and open public actions, Črnič (2007: 21) observes Drnovšek’s 
shift from a technocratic politician to a politician with a mission at the level of content and form, respectively. 'New' Drnovšek launched several initiatives for solving national and international issues, including humanitarian crisis in Darfur, which was supported by unusually intense communication activities, from media interviews, press conferences, press releases to official visits abroad. In his endeavours to 'save the world', he founded the Movement for Justice and Development (Gibanje za pravičnost in razvoj) aimed at social fairness, environmental protection and establishing a balance in society (Gibanje za pravičnost in razvoj, 2006). The foundation of such non-party associations, which act as a moral corrective outside the conventional political frameworks, is common for Slovenian top politicians (Lukšič 2006), yet Drnovšek's Movement differed in terms of public visibility and New Age activistorientation, particularly manifested in his blog on the Movement's website (cf. Anderson, 2003). At first informative discourse aimed at the members of the Movement was gradually replaced by critique of governmental policies, political, religious and social institutions, corporations, consumerism, social values, environmental issues as well as personal-reflective writings on raising consciousness, positive energy, peace, justice and inner balance (Črnič 2007: 23). His criticisms and activities in domestic and foreign affairs without prior conciliation or even opposing the Government led to political conflicts and disputes. As summarised by Trampuš (2006: 19), “besides the President, Slovenia got a spiritual leader, who argues with the Government", not because he was interested in political games of power or competing for public opinion support and popularity as is common for political leaders in modern democracies (Froehlich and Rüdiger, 2006; Voltmer, 2006), but because he wanted to expose irregularities and tell the truth, regardless if it harmed him or not (Črnič 2007; Repovž 2007).

Drnovšek did not only change his public image and actions, but also his lifestyle. He moved from the capital Ljubljana to a peaceful, remote rural village of Zaplana, became vegan and 
started growing organic food, which - as typical death-prevention behaviour (Hinton, 1972) was presumably Drnovšek's reaction to his illness. Drnovšek had a cancerous kidney removed in 1999 and when doctors discovered metastases on his lungs and liver in 2001, he started rejecting conventional medicine and first turned to alternative medicine, which he abandoned in 2005 and turned to a natural treatment guided by his 'inner feeling' (Črnič, 2007). Being aware of Drnovšek's cancer history, the public and the media were guessing if his change is related to his physical (and occasionally - with comments that the President has lost his mind - mental) illness (Mladenović, 2008), yet Drnovšek, while admitting that the illness acted as a shock, awakened him and enabled him to achieve higher levels of consciousness (BBC, 2008), persistently and firmly denied its existence (Žerdin and Pirc, 2008).

In 2007, Drnovšek in contrast to his intense post-transformation activities started gradually withdrawing from the public, cancelling his official duties as well as resigning as the leader of the Movement. The withdrawal was also reflected in a sharp drop of his public communication through the official channels (in 2007, there were 127 news messages published on the President of the Republic of Slovenia website in comparison with the record amount of 433 in 2006) as well as on the Movement's website (in 2007, he published 32 blog posts in comparison with 70 in 2006) as shown in Figure 1. The last time Drnovšek appeared in public, visibly weaker and thinner, was on 23 December 2007, when he handed over his presidency to the new President Danilo Türk. Two months later, on 23 February 2008, Janez Drnovšek passed away with no cause of death given. His death represents a symbolic end of post-socialist transition, with which Slovenia lost a great politician, who albeit challenging social values and hegemonic ideologies with his independent attitude, different approach and spiritual dimension towards the end of his political career, evoking affinities in public, yet surprise and unease in political circles, remained one of the most popular and trusted Slovenian politicians (Vreg, 2004; Črnič, 2007; Kovač, 2008; Žerdin and Pirc, 2008). 


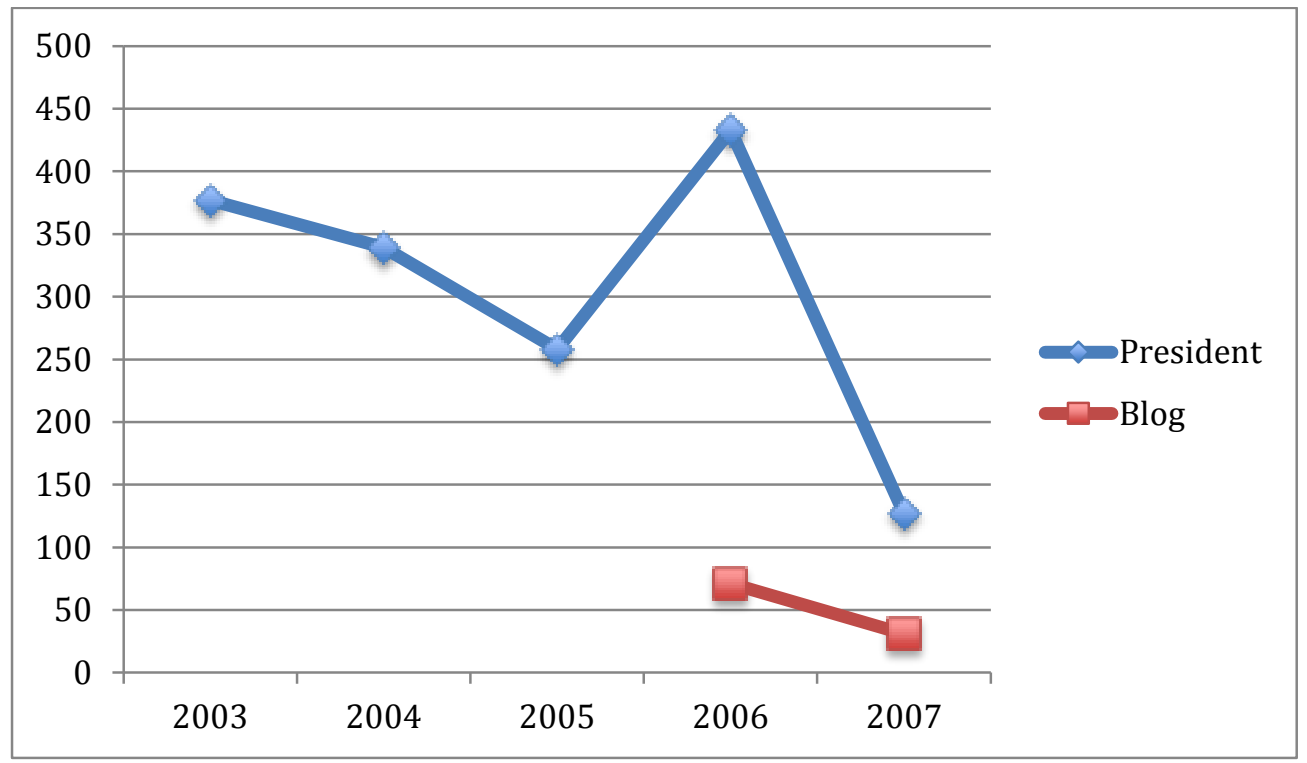

Figure 1. Number of messages on the President of the Republic of Slovenia website and blog posts on the Movement for Justice and Development website during Drnovšek's mandate.

\section{Thanatological and religiological perspectives on Drnovšek's change}

\section{Change as a reaction to facing mortality}

Despite Drnovšek's public denial of his illness - representing a common coping strategy as an individual in public office wishes to remain in a position of power, not to be treated differently by the environment (Kearl, 1989; Kübler-Ross, 2009), in which death and the process of dying represent a taboo (Brecker, 1973; Zgonik, 2011) -, the symptoms of a reaction to his mortality were clearly manifested in his radical change, driven by unexpected, impulsive and occasionally irrational cognitions, emotions and behaviours (Kearl, 1989; Elias, 2001; KüblerRoss, 2009). When faced with death, we become deprived of our future, which Koenig (in Kearl, 1989: 488) compares to personal bankruptcy - nothing relevant can no longer be lost, given or taken from an individual. Released from social and institutional pressures, norms and expectations, 'the beast' in us comes to the surface and starts representing a serious challenge 
to explanatory schemes of individual's behaviour (Kearl, 1989), evident in Drnovšek's deviation from conventional politics. His sharp criticisms of status quo and strong personal commitment to 'save the world' right now or as soon as possible are typically indicators of changed perceptions of time and priorities as well as anger in terminally ill patients (KüblerRoss, 2009). Kearl (1989) links these phenomena to the assumption that only when we think we are leaving this world, we start appreciating our legacy, which is also in line with Brecker's (1973) hero-systems, according to which we need to assure ourselves that we have achieved something of a lasting worth. In contrast to these intense activities, patients start in gradual acceptance of their fate isolating and systematically disengaging themselves from society in their final hours (Kearl, 1989; Elias, 2001; Kübler-Ross, 2009), as also visible in Drnovšek’s withdrawal from the public.

The process of dying is throughout accompanied by fear of dying and ontological anxiety in contemplation of our own death (Hinton, 1972; Brecker, 1973; Bryant, 2007), inevitably raising existential questions and beliefs in non-material existence, eternal life or life after death (Kearl, 1989; Kübler-Ross, 2009). While until recently, religion had a monopoly over the production of beliefs and cognitive knowledge of death, death-related behaviours and life after death, these became with secularisation of society jointly defined, explained and managed by religion, science, medicine and philosophy (Hinton, 1972; Kearl, 1989; Elias, 2001). Drnovšek publicly rejected religion and medicine, but increasingly turned to philosophy in addressing fundamental questions of human existence, the meaning of life and death, eternity and other spiritual themes (Črnič 2007, cf. Kübler-Ross, 2009), particularly in his blogs and spiritually philosophical books published in 2006 and 2007. In one of his blog posts, Drnovšek (2007) conceptualised death as a transmigration of the soul and continued spiritual existence and advised that we can only overcome the fear of death if we exceed our attachment to life, i.e. material existence. 


\section{Transformation as a New Age turn}

Drnovšek's meaning of existence, conceptualisation of human beings, understanding of religious traditions and institutions, personal commitment to save the world, emphasis on irregularities and critical attitude towards social trends besides a reaction to his mortality clearly indicate New Age origins, which led Črnič (2007) to conceptualise Drnovšek's change as a religious turn to new, alternative spirituality. The New Age movement labels a shift from Newton-Cartesian paradigm dominated by conflicts, hierarchies, wars, reductionism and materialism to softer holistic, spiritual, ecologic and systemic paradigm, based on Eastern philosophy (Črnič, 2007). This paradigm emphasises interconnectedness of all organisms and brings above average spread vegetarianism, in Drnovšek's case even veganism. Črnič (2007: 27, emphasis in original) further argues that typical for New Age is also "an optimistic emotional orientation, which in contrast to traditional religious emphasis on the other side, focuses on life here and now and seeks to improve the world, in which we live." With this aim, the New Age activist movements commonly express "frustrations with the alienating forces of globalism, together with the perception that the existing political structures are ineffective in terms of instigating fundamental social and economic change" (Anderson, 2003: 125). While expressing antagonistic attitudes towards dominant ideologies, political forces, social irregularities and injustice with a hope for resolution is common for 'anonymous' individuals involved in such movements (Johnson-Cartee, 2005), Drnovšek was "the first politician at the level of president of state [or government], who started using paradigmatic New Age discourse in his public actions" (Črnič, 2007: 33). These peculiarities in combination with President's sharp attitudes, unconventional actions and public conflicts with the establishment generated extraordinary media attention. 


\section{Public communication surrounding Drnovšek's change}

\section{The Story of the Year: Drnovšek's transformation in the media news}

While media coverage of the president as the highest representative of state is not unusual (Johnson-Cartee, 2005), changed and controversial President Drnovšek with new spiritual image became extremely newsworthy (cf. Galtung and Ruge, 1965: McGregor, 2002). Adding to the rapid increase of his media presence was also his shift from a reserved uncommunicative, inaccessible and closed politician 'colder than ice' to a fundamentally more open communicator (Berzelak, 2008; Kovač, 2008), who was filling the front pages and adopting elements of presidential drama and political spectacle. The phrase "Drnovšek surprised/shocked again" became a common headline in the media news, his statements were often chosen as the Sayings of the Week and some media, including national broadcaster TV Slovenia, characterised him as Surprise of the Year 2006. It is not just the content, but also the quantity of media news that attracts attention; e.g. with 347 news items on Drnovšek in 2006, TV Slovenia reported on him almost daily. Drnovšek as a politician from a small, relatively insignificant country also generated an unusually high international media coverage, including New York Times, Financial Times, International Herald Tribune, CNN and BBC, while Al Jazeera English filmed a documentary on his for the world of high politics unusual activities (Trampuš, 2006; Črnič, 2007).

The amplification and magnitude of media reporting indicate that the stories of the 'loopy' President started adopting characteristics of media-hypes. These self-inflated and mediagenerated news waves, underpinned by exaggerations and distortion, often develop a life of their own, disproportionate to the relevance of the 'real' events, even to the extent, that they temporarily change "the criteria for news selection, resulting in an increase of news on similar incidents and thematically related events", creating a false impression of urgency (Vasterman, 
2005: 510). This raises an important question to what extent Drnovšek really became as different, unconventional and eccentric as media, which at the time with privatisation and liberalisation of Slovenian media space found itself in a crisis of ethics and responsibility (Poler Kovačič, 2005), portrayed him. While Trampuš (2006: 18) believes that there is "a few light years" difference between 'old' and 'new' Drnovšek, Golobič (2008) emphasised that Drnovšek's personal transformation was not a radical jump; the themes were on his agenda before, he only changed the emphasis from a formal to everyday and humane content. Jeklin (2008: 6) further admits that in the last years of his mandate, "media did him great injustice" and can be deeply ashamed of several remarks they published, representing serious public relations challenges.

\section{Political public relations}

Modern public relations in Slovenia is a relatively young field, which intensively prospered and developed after Slovenian independence and is in theory "compatible to the current state of the profession in Europe at large" (Verčič, 2004: 379) with the practice lagging behind normative standards, in political somewhat more than in private sector (Verčič, 2004). Despite some encouraging developments in capacity building and professionalization in the new millennium, the practitioners in political sector still struggle with systematic and contentoriented issues in implementation of normative principles (Verčič, 2009; Serajnik Sraka et al., 2010), reflected in technical rather than managerial roles, one-way practice of information dissemination, general lack of trust and understanding of public relations' role and responsibilities, and a lack of expertise, education and experience of practitioners. Due to these immaturity issues and authoritarian organisational culture (Verčič, 2003), public relations advisers suffer from limited access to their superiors, decision-making processes and information (Serjanik Sraka and Vidrih, 2001). This does not seem to be an issue for other senior political advisers (Vreg, 2004; Lukšič, 2006), who do not only have a privileged access 
to a politician, but also regardless of their public relations expertise play an important role in strategic communication management, solving complex communication problems and managing relationships with the environment, while public relations advisers are "still treated as a technical function responsible for information and broadcasting” (Verčič, 2004: 382) and almost exclusively focused on media relations, representing one of the most important, if not the only specialisation of public relations (Verčič and Ažman, 2002; Furman, 2010; Serajnik Sraka et al., 2010).

Presidential public relations and relationships with journalists. While there is hardly any literature on public relations at the level of Slovenian president of state, Drnovšek's Office of the President website with most of its content intended for the media, clearly demonstrated emphasis on media relations (Predsednik Republike Slovenije, 2007). This was further confirmed in a media interview with his Public Relations Adviser Jana Lutovac Lah, who in a response to the question what a good public relations practitioner needs to have explicitly tied skills to media relations: "I can hardly imagine a good PR practitioner, who is not familiar with journalist work /.../ I think it is the essence to build a mutual relationship of understanding and respect, not a hierarchy, because in this relationship, it is all about cooperation." (Bakarič 2007: 36).

This statement indicates Office's endeavours to establish sweetheart relationships with the media, even though studies on governmental public relations in Slovenia (Serajnik Sraka and Vidrih, 2001; Verčič and Ažman, 2002) suggest the opposite by documenting love-hate relationships, underpinned by conflicts, mistrust, hostility, deceits and mutually manipulative practices with anything but positive opinions of the 'other' side. Sweetheart relationships observed in several other studies (Curtin, 1999; Shin and Cameron, 2003; Shaw and White, 2004; Johnson-Cartee 2005; Sallot and Johnson, 2006; Neijens and Smit, 2006; Davis, 2010; 
Ross, 2010), on the other hand, stand for symbiotic, reciprocal, consensual, mutually dependent and co-operative relationships, sustained by commitment, openness, relational satisfaction, likeability, mutual understanding, and most importantly trust (Jahansoozi, 2006). The facilitation and maintenance of such relationships is in the domain of public relations practitioners, who utilise impression-management strategies, including individual and professional approach, accessibility, responsiveness and providing exclusive information, advice, guidance and informal chat (Rijavec, 1998; Poler Kovačič, 2002; Johsnon-Cartee, 2005; Laban, 2007). Malenšek Kojić (2007) observes that these relationships often develop beyond professional necessity and grow into cordial personal relationships, even friendships, particularly in cases when interactions are frequent, intense and develop in small communities ${ }^{1}$ (cf. Shin and Cameron, 2003; Berkowitz and Lee, 2004). Poler Kovačič (2005: 34) warns that the 'cosiness' of such relationships might lead to journalists giving up their logic to consent to political rules of the game, while Larsson (2006) also emphasises that there needs to be a healthy scepticism between the two sides to preserve legitimacy of both professions.

Besides an indication of sweetheart relationships, there was another particularity in Drnovšek's public relations, introduced after his change - his 'private' blog on the Movement for Justice and Development's website. With a typical New Age discourse (Črnič, 2007), blog significantly differed from the official discourse of the Office of the President as well as promotional discourse of other political blogs, often written by communication advisers rather than politicians themselves (Grefe and Castleman, 2005). As the author and the first blogger among Slovenian politicians ${ }^{2}$, Drnovšek emphasised that he does not write the blog as president

\footnotetext{
1 With a population of only two million, Slovenia has a relatively small journalistic and political community. Journalists, politicians and their advisers are very likely to share similar social (e.g. family, friends), career or educational backgrounds.

2 That Drnovšek was the author of the blog was - besides a clear distinction from the official presidential discourse, which was indeed written by his advisers and unlike the blog posts edited and proof read confirmed by the respondents participating in this research. In addition, his spiritually philosophical books published in 2006 and 2007 to a large extent originate from his blog posts.
} 
of state, but as the leader of the Movement and a private citizen. This clear, yet unusual separation between the official president Janez Drnovšek and private citizen Janez D. (as he often signed his blog posts), characterised as schizophrenic personality (Trampuš, 2006), triggered controversies, where are the boundaries between private and official opinion of an individual in public office. These specifics in his communication support Serajnik Sraka and Vidrih's (2001) assumption that organisation of public relations is dependant on a personality of a politician, leading to the central question of this study; to what extent Drnovšek's personal transformation influenced his public communication and relationships with the media.

\section{Methodology}

\section{Research purpose and questions}

The purpose of this study is to examine the implications a radical transformation of a politician facing mortality has for communication phenomena and actors involved in the social construction of politics. The general question 'How radical personal transformation and shift in public actions of a politician with terminal illness influence media, public relations and relationships between the two?' is divided into the following sub-questions:

1. What were the journalistic perceptions and opinions of Drnovšek's transformation in comparison with perceptions and opinions of political advisers?

2. What were the implications of Drnovšek's transformation for journalists and media reporting?

3. How was Drnovšek's transformation reflected in his communication and public relations?

4. How Drnovšek's change influenced relationships and communication processes between the Office of the President and the media? 


\section{Methodological approach, data generation, analysis and ethics}

Given a relatively under researched area, the study adopted interpretativistic grounded theory approach (Strauss and Corbin, 1998) by conducting qualitative expert interviews (Bogner and Menz 2009; Littig 2009) with four Drnovšek's political advisers ${ }^{3}$ and eight political editors and journalists in the summer 2007, during Drnovšek's gradual withdrawal from the public. The sampling strategy consisted of deliberate sampling and snowball sampling, respectively (Cohen et al., 2011). Albeit small, the sample reached saturation point and included heterogeneous actors who were with different expertise, knowledge and at various stages of their careers at the forefront of public relations activities, media reporting and interactions between the two in times of Drnovšek's transformation. The interviews, lasting from 20 minutes to 1 hour with an average duration of 40 minutes, were recorded, transcribed and analysed with NVivo. The data analysis was based on the process of open, axial and selective coding, conceptual categorisation governed by a theoretical saturation and generation of abstract assumptions (cf. Strauss and Corbin, 1998; Bazeley, 2007). The interviews adhered to four essential ethical principles (Christians, 2005): (1) obtaining informed consent from the respondents, (2) avoiding deception or deliberate misrepresentation of the study, (3) protecting respondents' privacy and confidentiality, and (4) assuring accuracy of participants' words in data analysis and interpretation. Off the record information shared outside the official part of the interviews was not used in the study.

\section{Research criteria and limitations}

Subjectivity and bias in interview data generation were tackled with adhering to reliability, validity and generalisation criteria in qualitative terms. Reliability was reached through

\footnotetext{
${ }^{3}$ In line with immaturity issues, it was not only public relations, but also other Drnovšek's political advisers, who were involved in communication and relationship with journalists and were, therefore, included in the study.
} 
systematic and consistent sampling, data generation, analysis, and formulation of with evidence supported conclusions. Validity was established with (1) symbolic representation of the sample, while admitting that different sampling strategy and sample coverage might have yielded different results, (2) constant self-reflective and comparative method within empirical data and between data and theoretical assumptions, (3) comprehensive data treatment, (4) deviant case analysis, and (5) refutability principle, increasing explanatory potential of the study (Lewis and Ritchie 2003; Silverman 2006). Given the specifics of Drnovšek's case, findings allow for representative generalisation within this case with a strong inferential generalisation potential from the context of this research to similar phenomena in other socio-political contexts (cf. Lewis and Ritchie, 2003; Cohen et al., 2011).

\section{Findings and discussion}

\section{Perceptions and opinions of Drnovšek's transformation}

Opinions and perceptions of Drnovšek's change differed significantly between journalists and political advisers. While the latter expressed neutral views, the journalists clearly emphasised the difference between 'new' and 'old' Drnovšek.

Advisers: Naturalisation of the change. The advisers emphasised that they have no specific opinion of Drnovšek's 'change', attributing it to media's exaggerations of President's eccentricity rather than the President himself and in line with Golobič (2008) described it as "nothing new". They emphasised that if the President changed, he changed for the better. His activities, particularly educating and enlightening the public, were rather than unusual and unconventional described as an important upgrade of his constitutional duties and responsibilities. Their views closely resembled Drnovšek's comments in the media, which indicates a strategic harmonisation of official messages in the background and suggests that 
the advisers, who were professional communicators, might have spoken with an institutional rather than personal voice (cf. Littig, 2009). Only one adviser, at the time of the interview not employed by the Office of the President, explicitly emphasised that the President is a different person and while commending some of his moves, strongly disagreeing with others; this opinion was closer to journalistic views.

Journalists: Radical change. The journalists strongly emphasised Drnovšek's change with phrases such as "the President became different", "this is new Drnovšek", and even "he became weird". As summarised by one of the editors:

The President from Janez Drnovšek, a strict, serious, official politician, reached a new level, with which we can either agree or disagree, but he first and foremost became different. He was no longer a strict politician we once knew from his Prime Minister times, when he really was a politician with precisely defined rules, not deviating from normative standards. And at one moment, media realised that the President has changed his style of leadership or interest in strict understanding of politics and became a different president. He also changed his lifestyle, /.../ moved to a location that is by no means presidential residency, decided to take up ascetic life, for vegetarianism, for healthy life surrounded by people, who are not giving him negative energy, for consulting people, who are dealing with this.

In a similar manner and in accordance with Črnič (2007), other journalists observed Drnovšek’s change at interlinked levels of content and from, resulting in an "unpredictable president full of surprises". At the level of content, the journalists highlighted the transfer of Drnovšek's attention to 'different things', including previously strictly protected personal life, spirituality, social issues, 'saving the world', ecology and critique of the government and politics. At the level of form, they emphasised an obvious transition from background activities to intense, open and heterogeneous communication, strong engagement in activist-oriented actions and changed lifestyle. Some journalists emphasised that by becoming a strong critic of the Government and also being accepted as "the one who is against", Drnovšek not only played a role, but also represented the strongest opposition in the country. With additional "soloing in 
foreign affairs" without prior conciliation with the Government and the foundation of the Movement for Justice and Development, the journalists considered his actions as "walking, but never overstepping the edge of constitutionally acceptable". Even though, according to one of the respondents, his transformation at the beginning brought freshness into the political sphere and evoked undisputed affinities, it eventually led to saturation and overload due to Drnovšek's excessive comments, statements and deviations from normality.

Explanations of the change. Drnovšek's eccentric behaviour was in journalistic circles often related to doubts in his mental health. One of the journalists emphasised that "coalition simply believes that our president has gone a bit mad", while another journalists emphasised that some "superiors expressed expectations that it should finally be said that Drnovšek is really loopy". Only four respondents saw the transformation as a reaction to his illness. An editor emphasised that after defeating the disease, Drnovšek realised that it is important to change and has decided to enlighten the public, while his former adviser said that his illness represented trying experience, which changed his worldview and communication style. Two other journalists suggested that the illness is still present, but only mentioned it in passing. Rather than to physical illness, the respondents most commonly attributed Drnovšek's transformation to his 'reason gone mad', probably because of Drnovšek's public denial and/or taboo status of terminal illness, death and dying in Slovenia (Zgonik, 2011). None of the respondents related his change to a New Age turn, despite mentioning some New Age elements of it (e.g. raising consciousness, spirituality, emphasising irregularities and lifestyle).

\section{Changed media routines and portrayals}

Drnovšek's unconventional, unexpected moves caused a shift in media culture, visible in a transition from treating Drnovšek as a relatively uninteresting and closed politician with high level of authority, respect and awe, almost forgotten by the media, to Drnovšek as always good 
story, the amplification and magnitude of which was, according to the advisers, disproportionate to the real events and their relevance. These elements of media-hypes were also indicated in journalists' responses. One of them illustrated that Drnovšek statements were "always a peak, regardless of what he said, but he was for a while by default the first story at seven",, with another one emphasising that journalists even started assuming that Drnovšek would, whenever and wherever he appeared in public, offer new surprises or trigger controversies.

Changes in journalistic routines. With a 'you never know' attitude, journalists started attending the events not because they were newsworthy, but because the President was there. According to one of the respondents, journalists were "frantically rushing after Drnovšek" in a very active and occasionally even aggressive way with some "jumping from behind the ficus" to get his statements, which was uncommon for Slovenian journalism at the time. Another important change in journalistic routines was that for the first time in Slovenian media history, blog was treated as an important, official source of information, intensively followed and quoted in the news media, even though Drnovšek wrote it as a 'private' citizen. However, the journalists adopted an attitude that if an individual is in office of president of state, his expressed attitudes are always attitudes of the president, regardless if you sign them as Janez D. As emphasised by one of the journalists:

In the morning, we first read the Movement for Justice and Development website to see if the President has published anything new, which is sort of phenomenal, but this is the game that we had to play, because it would be ridiculous to ignore Janez D., if we all know that this is President Janez Drnovšek. Lowering the news threshold for events and statements related to the President indicated an important change in journalistic perceptions of news values and by altering their routines to

\footnotetext{
4 The central evening news programme on Slovenian public TV Slovenia as well as commercial POP TV starts at seven o'clock in the evening.
} 
get good stories, journalists consented to the political rules of the game, not because of the 'cosiness' of relationships with his advisors as Poler Kovačič (2005) suggests, but because of Drnovšek's radical change.

Exaggerations and incorrectness. With saturation of Drnovšek's surprising, occasionally funny and absurd actions in the media, the stories started losing respectful tone, portraying him in unconventional and informal social situations and diminishing his political reputation and credibility. Particularly famous was the example of the President with the wreath (Image 1), the image that was taken during a brief folk ceremony at the gathering of the Movement for Justice and Development in 2006, but started intensively circulating in the media as a symbolic representation of the transformed President. One of the journalists admitted that this portrayal of the President "perhaps in an undertone represented /.../ an attempt to show his weirdness" or, as emphasised by another journalist, as someone "who is not in the right state of mind or does not take his function the way he should". These portrayals had international implications, as stated by one of his advisers [emphasis in original]:

The Sunday Times once wrote that our President lives in a cottage and that he /.../ covers himself with leafs. But why? Why would The Sunday Times write that? Not because The Sunday Times would want to harm our President, not because they wanted to harm Slovenia, but because they summarised Slovenian media.

These kinds of intensive portrayals in the media are unusual and inappropriate for president of state and the journalists in line with Jeklin (2008) admitted certain level of media incorrectness in their coverage of Drnovšek. 


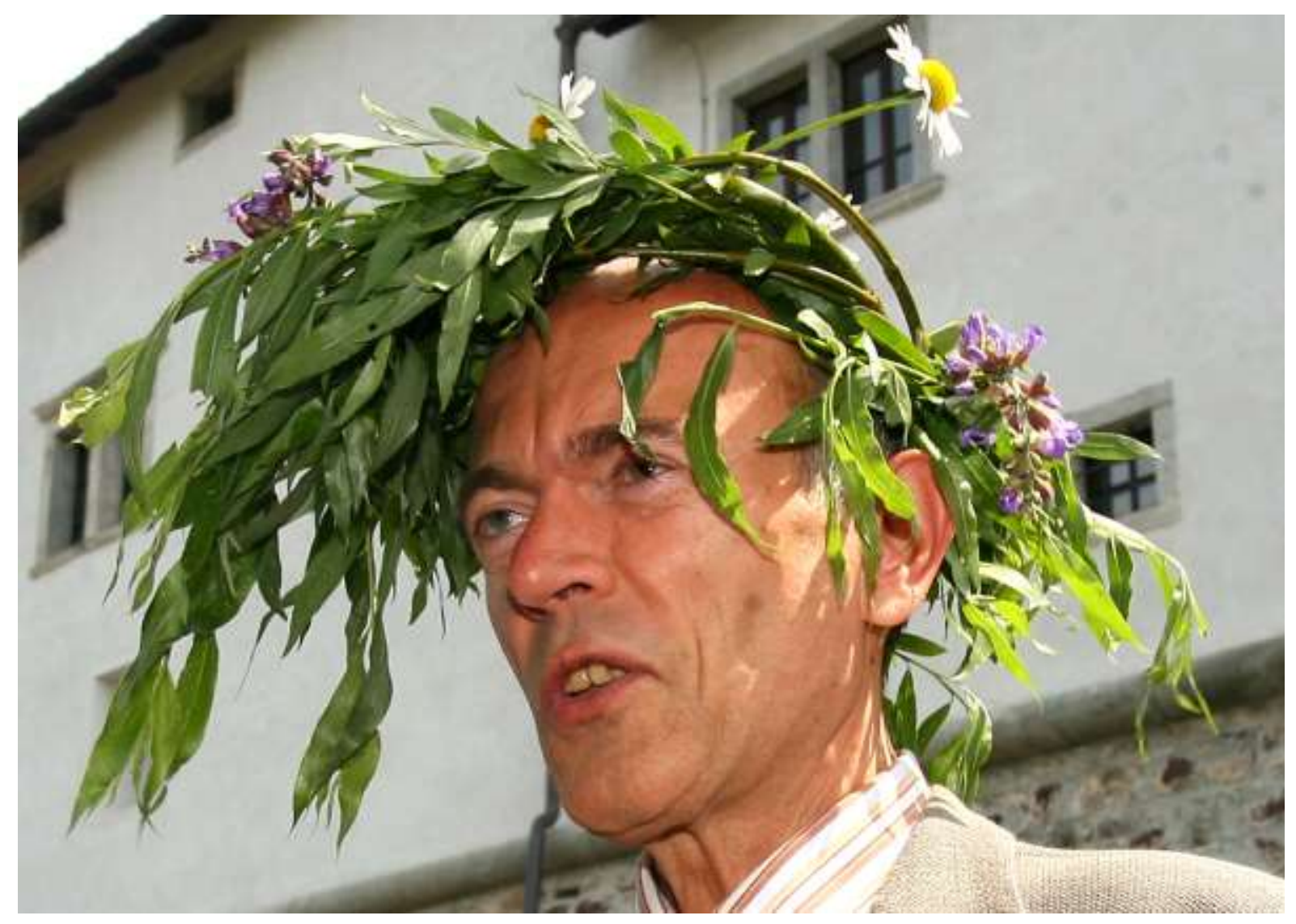

Image 1. Drnovšek with the wreath.

\section{Drnovšek's communication and public relations practices}

The increased media presence of Drnovšek was, according to the journalists, also due to his transition from a relatively closed, reserved and incommunicative politician, who with an exception of official duties rarely communicated with the media, talked cautiously and was a man of few words (cf. Vreg, 2001, 2004; Repovž, 2007; Berzelak, 2008; Kovač, 2008) to a more human, open and accessible political personality (cf. Golobič, 2008). Access to Drnovšek became much easier, also in unconventional ways, amongst which journalists emphasised personal meetings and invitations to his home in Zaplana, where during conversations on political issues they participated in very personal activities, including baking bread and walking his dog. His communication with the media became far more frequent, open and relaxed, yet 
at the same time more complex. As emphasised by the journalists, the President himself became very unpredictable, inconsistent and capricious in his media activities, either communicating intensively inside and outside of conventional frames or not communicating at all.

Official vs. informal President. Complexity, intensity and unpredictability of communication were increased with a split between official channels of President Janez Drnovšek and informal channels of a private citizen Janez, D. While the Office of Janez Drnovšek communicated through for political institutions conventional media relations tools (e.g. press conferences, statements, announcements of events, official website, emails, phone calls, meetings etc.), Janez D. started opening new communication channels with the media, most visibly the blog, which represented new phenomena in Slovenian political and media space. As emphasised by one of the journalists, "this way of informal communication chosen by the President was completely new; it has not been done by any top politician so far". However, this clear separation did not necessarily mean that official attitudes and views of the President were only communicated through the official channels. As emphasised by one of the editors, Janez D. was occasionally giving all relevant statements, which would have been expected from President Janez Drnovšek. While his informal channels were new, there were no changes in the President's official public relations and methods of communication with journalists.

Two-track system and immaturity issues. Even though the results of the interviews confirmed Serajnik Sraka and Vidrih's (2001) assumption that organisation of public relations in a political intuition depends on a personality of a politician, Drnovšek's official communication with the media remained unaffected by his personal transformation. Before and after the change, President Drnovšek represented a different politician with a peculiar organisation of public relations, manifested in a two-track system. This meant that the journalists communicated with the Office of the President through (1) public relations adviser, and more 
importantly (2) chief of the office and other senior advisers, who were (informally) authorised to provide official statements and speak on behalf of the President or his Office to and in the media. Confirming immaturity issues of public relations profession, interviews indicated that the role of the public relations adviser, whose key tasks included writing press releases, organisation and coordination of president's schedule, interviews and events, distribution of official statements, website editing, serving as the first point of contact and responding to journalistic questions, was purely technical and operational, while the more important contentoriented role was in the domain of the chief of the office and other advisers. Which one of them journalists contacted depended on a subject and personal relationships. One of the journalists stated:

[These advisers] are literally my sources, whereas [public relations adviser] is more the one, who then organises the work. /.../ [With the advisers] you also go for coffee, talk about informal matters, whereas with PR you work entirely on organisational matters.

Some journalists, in line with Poler Kovačič (2005), emphasised the problematic of 'cosiness' of these relationships, not so much in terms of political influence, but lack of formality. They believed that the Office of the President should have - like other top politicians and as theory suggests (Rijavec, 1998; Serajnik Sraka and Vidrih, 2001; Verčič et al., 2002; Cutlip et al., 2006) - more strictly formalised communication with the media, organised through public relations office rather than a relaxed, spontaneous, personal and informal structure, subject to personal acquaintances. With the advisers confirming that their communication with journalists is based on improvisations, educated guess and personal relationships, the findings lend little support to the assumption that Drnovšek's public relations were strategically managed and planned before or after his public transformation. 


\section{Unchanged relationships between political advisers and journalists}

In accordance with unchanged public relations practices, the relationships between political advisers and journalists also somewhat surprisingly remained the same after Drnovšek's transformation. As emphasised by one of the journalists, he has changed, yet his advisers and their relationships with journalists stayed the same. A closer examination reveals that relationships between journalists and Drnovšek's advisers adopted a sweetheart rather than love-hate form. All the respondents positively evaluated their relationships with the 'other' side and described them as being 'correct' (which in Slovene language means 'in accordance with norms', 'considerate', 'not misleading' or 'deceitful'), very good, professional, normal, occasionally also friendly and excellent. None of the respondents mentioned conflict or confrontational dimensions of relationships, deceit, manipulation or frustration with the 'other' side. While there was a healthy level of scepticism between the two sides in terms of awareness that they work for 'two opposite sides' and that there are contradictions in their goals and interests, they at the same time expressed a commitment to seeking compromise and establishing good and professional relationships, which are of extreme importance and play a significant role in political access to media discourse as well as in journalistic access to political information. Being aware of the benefits of good relationships, it was - in contrast with the literature (cf. Rijavec, 1998; Johnson-Cartee 2005) - not just political advisers, but also journalists, who were striving for their establishment, maintenance and protection with both sides utilising impression-management strategies; the advisers mostly through openness, responsiveness and accessibility and the journalists through maintenance of regular contacts and interactions with the advisers. Their long-term oriented relationships, underpinned by high levels of trust, occasionally went beyond professional necessity and grew into informal personal relationships or even friendships, the relevance of which was emphasised by all the 
respondents with four journalists and one adviser considering them as the most important part of their job.

In line with sweetheart dimensions of the relationships, journalists' opinions of political advisers were - unlike the existing studies suggest (Serajnik Sraka and Vidrih, 2001; Verčič and Ažman, 2002) - very positive. They described them as correct, accessible, responsive, open, honest and reliable professionals, preforming sophisticated roles in assisting journalists with gathering information and understanding complex political issues. The only negative comment the journalists had was that occasionally it took very long to get information from the Office or that the advisers decided "not to communicate". However, the journalists assigned responsibility for this to Drnovšek, stressing that his advisers are "not to blame" and "are doing all they can, but the President is capricious and unpredictable", putting them in an "unpleasant position, in which they cannot do their job properly". While the journalists expressed highly positive, understanding and empathic attitudes towards the advisers, the advisers described journalists in somewhat less positive way, but emphasised that they could not generalise. Even though their relationships, particularly from the advisers' side, might have encompassed lovehate dimensions, they still represented stable and enduring structures resistant to a radical public transformation of a politician facing mortality.

\section{Conclusion}

Despite representing one of the most successful politicians in Slovenian history, Janez Drnovšek was often labelled as a 'non-politician among politicians'. Prior to his change, he was known as a technocratic politician, who built his reputation in an unusually reserved and incommunicative way with low interest in populist approach, media visibility and strategies of media appearance (Vreg, 2001, 2004; Črnič, 2007; Repovž 2007; Berzelak, 2008; Kovač, 2008). This attitude radically changed with his personal transformation in 2006, when 
Drnovšek with new directness, openness, media omnipresence and critical orientation increasingly acted as a spiritual leader. While New Age paradigm offers an important contextual reference framework of his shift (Črnič, 2007), thanatology perspective provides a more holistic approach to understanding his deviation from conventional political actions as a reaction to terminal illness (Kearl, 1989; Elias, 2001; Kübler-Ross, 2009), the existence of which Drnovšek persistently denied. Despite a few passing mentions of physical illness in the interviews, the journalists, emphasising the significance of his transformation, tended to attribute Drnovšek's actions to his mental status and insanity. The political advisers, on the other hand, adopted a protective and defensive attitude towards the President, ascribing the 'change' to media exaggerations of President's eccentricity. While partly admitting responsibility for exaggerated and occasionally incorrect coverage, the journalists emphasised that increased media presence of Drnovšek was due to his surprising attitudes and actions as well as more open style of communication with the media. These triggered changes in journalistic routines in terms of increased newsworthiness of events and issues related to the President, intensity in gathering information and unconventionality in reporting, while the organisation of the Office of the President's public relations and sweetheart relationship structures with the media remained the same, indicating their endurance and resistance to a radical political transformation in the process of public dying. In the last period of his life, Drnovšek significantly (co)shaped media discourse as a result of his personal transformation and changed journalistic routines rather than well-thought-out public relations strategies or endeavours to influence media content.

The findings of the study contribute to an understanding of complex and contextually-specific communication phenomena surrounding one of the most radical political turns in history of independent Slovenia (Lukšič, 2006; Črnič, 2007) with a strong potential to serve as a reference point for future research on how death and public relations is handled in different socio- 
political contexts, some famous examples including Venezuela President Hugo Chávez and Hungarian Prime Minister József Antall. This area might become of a significant importance in the future with Bryant (2007) forecasting that the number of persons diagnosed with terminal illness will expand significantly due to medical accomplishments and technical advances (cf. Zgonik, 2011); even political institutions made up of the individuals classified as terminal is not beyond the realm of possibility. The potential increase in political figures facing mortality and public manifestations of death-related personal feelings, attitudes, believes and behaviours bring important implications and repercussions in terms of media and public relations as well as broader cultural and political shifts indicated in Drnovšek's case (Lukšič, 2006). In this sense, the process of dying is of a much greater social and political importance than currently acknowledged (van Brussel and Carpentier, 2014), including in the area of public relations of dying public figures.

\section{References}

Anderson A (2003) Environmental Activism and News Media. In: Cottle S (ed) News, Public Relations and Power. London, Thousand Oaks, New Delhi: Sage, pp.117-132.

Bakarič D (2007) Jana Lutovac Lah, svetovalka predsednika republike Janeza Drnovška za odnose z javnostmi: "Predsedniku sem v oporo!". Obrazi, 15 June, 12.

Bazeley P (2007) Qualitative Data Analysis with NVivo. Los Angeles, London, New Delhi, Singapore: Sage.

BBC (2008) Slovenia independence leader dies. Available at:

http://news.bbc.co.uk/1/hi/world/europe/7260349.stm (accessed 15 March 2014).

Berkowitz D and Lee J (2004) Media relations in Korea: Cheong between journalists and public relations practitioner. Public Relations Review 30: 431-437.

Berzelak M (2008) Politik z velikim Č. Jana, posebna izdaja Zbogom predsednik, 25 February, XXXVI.

Bogner A and Menz W (2009) The Theory-Generating Expert Interview: Epistemological Interest, Forms of Knowledge, Interaction. In: Bogner A, Littig B and Menz W (eds) 
Interviewing Experts. Houndmills, Basingstoke, Hampshire, New York: Palgrave /MacMillan, pp.43-80.

Brecker E (1973) The Denial of Death. New York: The Free Press.

Bryant CD (2007) The Sociology of Death and Dying. In: Bryant CD and Peck DL (eds) $21^{s t}$ Century Sociology. Thousand Oaks, London, New Delhi: Sage, pp.56 - 166.

Christians CG (2005) Ethics and Politics in Qualitative Research. In: Denzin NK and Lincoln YS (eds) The SAGE Handbook of Qualitative Research. Thousand Oaks, London, New Delhi: Sage, pp.139-164.

Cohen L, Lawrence M and Morrison K (2011) Research Methods in Education. Oxon, New York: Routledge.

Curtin PA (1999) Reevaluating Public Relations Information Subsidies: Market-Driven Journalism and Agenda-Building Theory and Practice. Journal of Public Relations Research 11(1): 53-90.

Cutlip SM, Center AH and Broom GM (2006) Effective Public Relations. London: PrenticeHall International.

Črnič A (2007) Predsednik za novo dobo: religiološka analiza Drnovškovega obrata. Družboslovne razprave XXIII(2007)(56): 21-37.

Davis A (2010) Political Communication and Social Theory. Oxon, New York: Routledge.

Drnovšek J (2007) Rubrika. In: Gibanje za pravičnost in razvoj. Available at: http://www.gibanje.org/index.php?id=2788 (accessed 14 March 2014).

Elias N (2001) The Loneliness of the Dying. New York: Continuum International Publishing Group.

Froehlich R and Rüdiger B (2006) Framing political public relations: Measuring success of political communication strategies in Germany. Public Relations Review 32: 18-25.

Furman N (2010) Communicating Public Money: Risks vs. Opportunities. In: Verčič D and Sriramesh K (eds) Government Communication: Proceedings of the $17^{\text {th }}$ International Public Relations Research Symposium BledCom. Ljubljana: Pristop, pp.124-131.

Galtung J and Ruge MH (1965) The Structure of Foreign News. Journal of Peace Research 2(1): 64-91.

Gibanje za pravičnost in razvoj (2006). Available at: http://www.gibanje.org (accessed 16 April 2006). 
Golobič G (2008) Pogrešali bomo izjemnega državnika. Jana, posebna izdaja Zbogom predsednik, 25 February, XXXVI.

Grefe EA and Castleman SA (2005) Information, Communication Systems, and Technology in Public Affairs. In: Harris P and Fleisher CS (eds) Handbook of Public Affairs. London: Sage, pp.160-186.

Hinton J (1972) Dying. London: Penguin Books.

Jahansoozi J (2006) Relationships, Transparency and Evaluation: Implications for Public Relations. In: L'Etang J and Pieczka M (eds) Public Relations: Critical Debates and Contemporary Practice. Mahwah, New Jersey, London: Lawrence Erlbaum, pp.61-91.

Jeklin B (2008) Delali smo mu hudo krivico. Jana, posebna izdaja Zbogom predsednik, 25 February, XXXVI.

Johnson-Cartee KS (2005) News Narratives and News Framing: Constructing Political Reality. Lanham: Rowman \& Littlefield.

Kearl MC (1989) Endings: A Sociology of Death and Dying. New York: Oxford University Press.

Kovač B (2008) Simbolni konec tranzicije. Mladina, 29 February, 09.

Kübler-Ross E (2009) On Death and Dying: What the dying have to teach doctors, nurses, clergy and their own families. Oxon: Routledge.

Laban V (2007) Televizijsko novinarstvo: Hibridizacija žanrov in stilov. Ljubljana: FDV.

Larsson L (2006) Public Relations and Democracy: A Swedish Perspective. In: L'Etang J and Pieczka M (eds) Public Relations: Critical Debates and Contemporary Practice. Mahwah, New Jersey, London: Lawrence Erlbaum, pp.123-141.

Lewis J and Ritchie J (2003) Generalizing from Qualitative Research. In: Ritchie J and Lewis J (eds) Qualitative Research Practice: A Guide for Social Science Students and Researchers. Thousand Oaks, CA: Sage, pp.263-268.

Littig B (2009) Interviewing the Elite - Interviewing Experts: Is There a Difference?. In: Bogner A, Littig B and Menz W (eds) Interviewing Experts. Houndmills, Basingstoke, Hampshire, New York: Palgrave /MacMillan, pp.98-113.

Lukšič I (2006) Politična kultura: političnost morale. Ljubljana: FDV.

Malenšek Kojić T (2007) Odnosi med strokovnjaki za odnose z javnostmi in novinarji. Master Thesis. University of Ljubljana, Slovenia.

McGregor J (2002) Restating News Values: Contemporary Criteria for Selecting the News. In: Australia and New Zealand Communication Association International Conference: 
Communication - Reconstructed for the 21st Century, Gold Coast, Queensland, Australia, 10 -12 July.

Mladenović S (2008) Analitiki: O Drnovškovem mandatu težko podati enovito oceno. Available at: http://www.sta.si/vest.php?s=s\&id=1260583 (accessed 23 February 2008).

Neijens P and Smit E (2006) Dutch public relations practitioners and journalists: Antagonists no more. Public Relations Review, 32: 232-240.

Poler Kovačič M (2002) Vplivi odnosov z mediji na novinarski sporočanjski proces. Teorija in praksa 39(5): 766-785.

Poler Kovačič M (2005) Kriza novinarske odgovornosti. Ljubljana: FDV.

Predsednik Republike Slovenije (2007). Available at: http://www2.gov.si/up-rs/20022007/jd.nsf (accessed 14 March 2014).

Repovž G (2007) Intervju Janez Drnovšek: 'Kar se dogaja, je zunaj okvirov normalnega'. Mladina, 17 February, 07.

Rijavec P (1998) Odnosi z mediji. In: Gruban B, Verčič D and Zavrl F (eds) Preskok v odnose z javnostmi. Ljubljana: Pristop, pp.189-202.

Ross K (2010) Danse Macabre: Politicians, Journalists, and the complicated Rumba of Relationships. International Journal of Press/Politics 15(3): 272-294.

Sallot LM and Johnson EA (2006) Investigating relationships between journalists and public relations practitioners: Working together to set, frame and build the public agenda, 19912004. Public Relations Review 32: 151-159.

Serajnik Sraka N and Vidrih B (2001) Vladni odnosi z javnostmi: Model organiziranosti vladnih odnosov z javnostmi v Sloveniji. Teorija in praksa 38(4): 650-674.

Serajnik Sraka N, Kek M and Vidrih B (2010) Capacity Building in Government Communication - The Case of Slovenia: from Capacity Building to Professionalism. In: Verčič D and Sriramesh K (eds) Government Communication: Proceedings of the $17^{\text {th }}$ International Public Relations Research Symposium BledCom. Ljubljana: Pristop, pp.208220.

Shaw T and White C (2004) Public relations and journalism educators' perceptions of media relations. Public Relations Review 30: 493-502.

Shin JH and Cameron GT (2003) Informal relations: A look at personal influence in media relations. Journal of Communication Management 7(3): 239-253.

Silverman D (2006) Interpreting Qualitative Data: Methods for Analyzing Talk, Text and Interaction. London, Thousand Oaks, New Delhi: Sage. 
Strauss A and Corbin J (1998) Basics of Qualitative Research: Techniques and Procedures in Developing Grounded Theory. Thousand Oaks, London, New Delhi: Sage.

Trampuš J (2006) Janez D. Mladina, 22. December, 52-53.

Vasterman PLM (2005) Media-Hype: Self-Reinforcing News Waves, Journalistic Standards and the Construction of Social Problems. European Journal of Communication 20(4): 508530 .

Van Brussel L and Carpentier N (eds) (2014) The Social Construction of Death: Interdisciplinary Perspectives. Houndmills, New York: Palgrave Macmillan.

Verčič D (2003) Public Relations in a Corporativisit Country: The Case of Slovenia. In: Sriramesh K and Verčič D (eds) The Global Public Relations Handbook: Theory, Research and Practice. Mahwah: Lawrence Erlbaum Associates, pp.573-595.

Verčič D (2004) Slovenia. In: van Ruler B and Verčič D (eds) Public Relations and Communication Management in Europe: A Nation-by-Nation Introduction to Public Relations Theory and Practice. Berlin, New York: Mouton de Gruyter, pp.375-386.

Verčič D (2009) Public Relations in a Corporativisit Country: The Case of Slovenia. In: Sriramesh K and Verčič D (eds) The Global Public Relations Handbook Revised Edition: Theory, Research and Practice. Mahwah: Lawrence Erlbaum Associates, pp.281-300.

Verčič D and Ažman A (2002) Communication between government and citizens in Slovenia: A report \& recommendations. In: United Nations Development Programme Regional Bureau for Eastern Europe and the CIS UNDP RBEC sub-regional project RER/01/003/A08/13: 'Improving Communication from Government to Societies'. Ljubljana, Slovenia, 29 June.

Verčič D, Zavrl F and Rijavec P (2002) Odnosi z mediji. Ljubljana: GV Založba.

Vreg F (2001) Volitve 2000 in predvolilna kampanja. Teorija in praksa 38(2): 181-200.

Vreg F (2004) Politični marketing in demokracija. Ljubljana: FDV.

Voltmer K (ed) (2006) Mass Media and Political Communication in New Democracies. London, New York: Routledge ECPR.

Zgonik S (2011) Umiranje po slovensko: Tabu. Mladina, 28 October, 43.

Žerdin AH and Pirc V (2008) Dr. Janez Drnovšek. Mladina, 29 February, 09. 